\title{
INTERNATIONAL EXHIBITION,
}

In connexion with the International Medical and Banitary Exhibition which is to be held in London, before the meeting of the Medical Congress, it is hoped that our speciality will be well represented. Any improvements or modification of rooms, beds, dresses or appliances, will be welcomed. It is not yet decided whether in section viii of the Congress a special exhibition at Bethlem Hospital should take place or not. It will depend, to a great extent, on the way in which members respond to the invitation to cend novelties.

\section{Obituary.}

ISAAC RAY, M.D., LL.D.

With deep regret we record in this Journal the death of a distinguished alienist, an ornament to our special branch of the Profession, and the Nestor of Medical Psychology in the United States of America.

With Dr. Ray dies a vast mass of material stored up in a mind, acute in its perceptive powers, and quick to seize the relation of facts to principles. Indeed the swiftness with which he saw fallacies rendered him a little impatient of the detailed examination of questions in which truth and error were intimately blended.

"He commenced his literary education at Phillip's Academy, Andover, and afterwards entered Bowdon College, where be prosecuted his studies till 1824, when he was compelled to leave on account of ill health. Soon after leaving cullege, when his health had sufficiently improved, he commenced the study of medicine, passing a portion of the time in the office of Dr. Shattuck, a distinguiahed physician of Boston, and graduated at the medical department of Harvard University in 1827, in which year he began practice in the City of l'ortland, Maine, and he here married in 1831 Miss Frothingham, who survives him.

"Two yeare after commencing practice inducements were offered to him to remove to Eastport, in the same State, in which place he soun after fixed his residence. It was in Eastport that Dr. Ray's attention was first directed to the subject of insanity.

"In 1841 he was appointed Medical Superintendent of the Maine Hospital fur the Insane, at Augusta, which position he held till he was invited by the authorities of the Butler Hospital, at Providence, R.I., to hecome superintendent of that institution-which was just then being orgunised-and to supervise its erection. No one has done more to secure the proper organisation of American hospitals for the insane.

"Dr Rry was led to accept this position especially from the fact that that hospital was to be the offspring of private muniticence, and was to be controlled by men above all suspicion of political or selfish interest in reference to it. Beyond this, he was here offered an opportanity to introduce into the construction of the buildings and into the subsequent nanagement of the institution his well matured views on all these subjects."-Philadelphia Medical Times.

Befure commensing his duties Dr. Ray visited Europe, and if he often recurred to his visit to England with pleasure, those who formed his acquaintance in this country were not less delighted with his sterling worth, intelligence, sincerity, and the peculiar charm of his conversation when at ease. We recall what may seem too trivial to mention; but it illustrates the lasting impression he produced that a remark of his at the table of the house he made his home at York, is still remembered, as well as the particular tone in which he said it a propos of the subject at the moment discussed, "The nervous system," said he, "is an instrument on which we know not yet half the airs that may be played." His triend, Dr. Kirkbride, writes to us "It was necessary to know Dr. Ray iutimutely to appreciate him properly, and many who met him only in public XXVII. 
life had no conception of the charms that belonged to his social intercourse with those to whom he gave his friendship and confidence."

Dr. Ray's best known work, which appeared in 1839 , has deservedly retained the first place among works in the English tongue on the medical jurisprudence of insanity. The fifth edition was reviewed in this Journal in 1872, and we believe a more renent one has appeared. We should have been glad to see one still further enriched by his mature experience and with some points more fully worked out In his contributions to Mental l'athology, published in 1873, we have the principal papers which he had contributed to Mental Science, collected together up to that date, and a valuable selection it is. There have been many communications to the medical journals since from his pen which ought to be religiously preserved and presented in an accessible form to the public. Dr. Ray s life-work was done, properly speaking, in the twenty three years during which he laboured at the Butler Hospital, und in death he has, it is said, not forgotten to bequeath a handsome sum to this hospital.

"He continued to fill the office till January 1867, when, to the great regret of the authorities of the hospital and of all in any way interested in its welfare, be felt impelled by a conviction that his health recommended a change of climate and occupation, to resign the position which he had held so acceptably to all, and with such equal advantage to the afficted for more than 22 years."*

It is more than probable that Dr. Ray might have been longer spared to his friends and the profession had he not lost, about a year ago, his only son, a physician. His letters from that time were mostly sorrowful, but not querulous, and show how deeply he felt the loss of one on whom he had, in a sense, centred all his bopes in the future, and without whom he felt as if life was hardly worth living. He expressed himself to the writer as paralysed, and it was too true that listening to "the closing door," his life "was darkened in the brain," perfectly clear though his mind remained to the last.

Born at Beverly, Massachusetts, he died at Philadelphia, where he had lived many years, honoured and beloved. His end came on the last day of March at the age of 74. And so the sorrow-chastened veteran passed quietly away " into that still country," to use the language of Carlyle, "where the hailstones and fire storms do not reach and the heaviest laden way-farer at last lays down his load."

D. H. T.

\section{JAMES SHERLOCK, M.D., M.R.C.P.}

Dr. Sherlock, the Medical Superintendent of the Worcester City and County Asylum, died May 13, aged 53, after occupying his post, with the greatest satisfaction to the Committee, for twenty-seven years. He was a pupil of Dr. Skae, of Edinburgh and was at one time Superintendent of Janies Murray's Asylum at Perth. His loss is greatly deplored.

On May 10th he was seized with ucute hepatic congestion; the base of the right lung subsequently became involved, and then both lungs.

The Committee of Visitors in passing a resolution expressing their deep sorrow at the irreparable loss they and the County and City of Worcester have sustained, observe :- "Gifted with peculiar talents for the branch of the profession he embraced, Dr. Sherlock possessed a combination of powers seldom united in the same person. With a singularly correct insight into the various distinctions of peculiarities of mental aberration, and with much administrative ability and firmness of purpose, were associated exceeding kindness of heart ard disposition and the greatest suavity of manner, ensuring not only the confidence but the affection of all around him. By the visitors, attendants, and patients his qualities were highly appreciated, and his death painfully lamented."

$$
\text { * "Philadelphid Medical Times," April 23, } 1881 .
$$

